$\S=-1$

\title{
An Experimental Study on Fibre Reinforced Geopolymer Concrete Composites- Glass Fibre, Copper Slag
}

\author{
J Asanammal Saral ${ }^{1 *}$, S Gayathri $^{2}$, M Tamilselvi $^{3}$, and B Raghul Raj ${ }^{4}$ \\ ${ }^{1,2,4}$ Assistant professor \\ ${ }^{3}$ Professor ${ }^{1,2,3,4}$ Vel Tech High Tech Dr.Rangarajan Dr.Sakunthala Engineering College \\ Avadi, Chennai,Tamil Nadu, India. \\ *Corresponding author E-mail: asanammalsaralj@velhightech.com
}

\begin{abstract}
The major problem of the world is facing today is environmental pollution. It is well known that for the production of 1-ton of cement consumes more energy and exhibit 0.8 -ton of $\mathrm{CO}_{2}$. On the other hand Fly ash is a residue from the combustion of pulverized coal from the flue gases of thermal power plant. Recently, the fly ash is not effectively used and a large part of it is disposed in landfill. Due to this problem the various researchers have sort for a new binder to minimize the consumption of OPC. This study evaluates the strength of geopolymer concrete having fly ash as the major binding material and the sand a fine aggregate was replaced with copper slag of $40 \%$ and glass fiber to enhance the mechanical properties have been presented. This paper analyses on the mechanical properties of eopolymer concrete composites such as compressive strength, split tensile strength and water absorption in heat curing at $60^{\circ} \mathrm{C}$ for $24 \mathrm{hrs}$ in hot air oven. Glass fibers were added in the mix in the volume fraction of $0.5 \%, 1.0 \%, 1.5 \%$ and $2.0 \%$ volume of the concrete. The influence of fiber content in terms of volume fraction on the compressive, split tensile strength of geopolymer concrete is presented. The result shows the elevated performance of the properties exhibited by the geopolymeric concrete with and without fibres.
\end{abstract}

Keywords: Fly ash; alkaline liquids; Copper Slag; Glass Fibre; compressive strength.

\section{Introduction}

Concrete is a composite material, it is manufactured from Portland cement clinker and most widely used material on the world. The production of 1 ton of OPC (ordinary Portland cement) liberates about 0.8 ton of $\mathrm{CO}_{2}$ is released. Many efforts are being made in order to reduce the use of Portland cement in concrete but the demands for the concrete material is on increases worldwide and increase the demand for cement. The consumption of cement could be reduced by three ways, i) through economical mix design, ii) by replacing cement with fly ash by adopting high volume fly ash concrete, iii) by using alternate binding materials for concrete such as bacterial or geopolymer concrete. "Krishnan et.al. Hardjito et.al.," [1,2] examined the class F flyash based geopolymer concrete is an economical and eco friendly construction material. It was obtained from industrial solid waste and by product. Most of the flyash is not effectively used and a large part of it is disposed in landfills. The major advantageous of using flyash as follows: conserved landfill space, reduce $\mathrm{CO}_{2}$ emissions and saved energy. "Davidovits"[3] investigated the geopolymer concrete is an inorganic alumino-silicate polymer, synthesized from predominantly silicon and aluminum material such as fly ash. Alkaline solutions are used to induce the silicon and aluminum atoms in the source material to dissolve to form gel. Geopolymer cement is an innovative material and real alternative to conventional Portland cement for using transportation, infrastructure, construction and offshore application and it is the binding systems that harden at room temperature like regular Portland cement. The strength and durability of geopolymer concrete composites are good candidate construction material. It also bond strength of geopolymer concrete is higher than cement concrete. It does not utilize any Portland cement in it, however the binder is produced by the reaction of an alkaline liquid with a source material they are rich in silica and alumina. Geopolymer form three dimensional disordered framework of tecto-alumino silicate with the empirical formula $\left.\mathrm{Mn}\left[-\mathrm{SiO}_{2}\right]_{\mathrm{z}}-\mathrm{AlO}_{2}\right]_{\mathrm{n}} \mathrm{WH} 2 \mathrm{O}$, where $\mathrm{n}$ is the polycondensation, $\mathrm{m}$ is the predeterminantly a monovalent cation was discussed in detail by "Anuradha et.al. [4]".

The concept of using fibre as reinforcement is not new. By 1960, the steel, glass, synthetic fibres such as polypropylene fibres were used in concrete and research into new fibre reinforced concrete continuous today, some type of fibres produced high impact and abrasion resistance in concrete. "Weena Lokuge et.al." [5] examined the structural application for fibre concrete possesses many advantageous compared to the traditional structural concrete since it improve the tensile, cracking and other properties of concrete. The Fibre Reinforced geopolymer Concrete is a type of fibre reinforced concrete which is mainly used in exterior building façade panels as an architectural precast concrete. Addition of glass, steel and polypropylene fibres also to increase the split tensile strength and compressive strength of geopolymer concrete was discussed by "Vignesh et.al, Aslam hutagi et.al, Bhalchandra et.al, [6-8]. "Faiz Uddin Ahmed sheikh, Arnaud Castel et.al, Mahendran et.al," [9-11] was discussed with the replacement of sand with copper slag as fine aggregate in geopolymer concrete. The geopolymer concrete mix with copper slag attains maximum compressive strength and split tensile strength.

The main objective of this study on the mechanical properties of geopolymer concrete using copper slag and glass fibre such as 
compressive strength, split tensile strength and water absorption test were tested.

\section{Experimental Programme}

\subsection{Materials:}

Low calcium class $\mathrm{F}$ fly ash used in the experimental program was obtained from Tuticorin Thermal Power Plant, Tamilnadu, India The specific gravity of fly ash is 2.73 . The most commonly used alkaline activator as a mixture of sodium hydroxide and sodium silicate solution. For preparation of alkaline liquids, sodium hydroxide with $98 \%$ purity and sodium silicate is obtained from local manufacturer. In order to get 14 molarities, 616 grams of sodium hydroxide were distilled in 1ltr water. According to IS:383-1970, Locally available river sand was purchased, having a specific gravity of 3.73 and fineness modulus of 2.75. Copper Slag used is obtained from sterillite industries limited, Tuticorin, Tamilnadu, the specific gravity of the slag is 3.05 . Locally available $20 \mathrm{~mm}$ crushed aggregate having specific gravity of 2.85 .

\subsection{Mix Design and Specimen Preparation}

In this study the replacement of sand with copper slag in geopolymer concrete varying the percentage of $0 \%, 10 \%, 20 \%$, $30 \%, 40 \%$.For these proportions to take an optimum value , then added glass fibre in the mix of $0.5 \%, 1 \%, 1.5 \%$ and $2 \%$. The concentration of sodium hydroxide solution is $14 \mathrm{M}$. The conventional concrete and geopolymer concrete composites mixture was designed as per IS 10262-1982.

Table 1: Mix quantity of geopolymer concrete

\begin{tabular}{|c|c|c|c|c|c|c|}
\hline \multirow{2}{*}{$\begin{array}{c}\text { Mix } \\
\text { Identity }\end{array}$} & \multirow{2}{*}{$\begin{array}{c}\text { Fly } \\
\mathrm{Ash} \\
\mathrm{kg} / \mathrm{m}^{3}\end{array}$} & \multicolumn{2}{|c|}{$\mathrm{F} . \mathrm{Kg} / \mathrm{m}^{3}$} & \multirow{2}{*}{$\begin{array}{c}\mathrm{CA} \\
\mathrm{kg} / \mathrm{m}^{3}\end{array}$} & $\begin{array}{c}\text { Alkaline } \\
\text { Liquids }\end{array}$ & Water \\
\cline { 3 - 4 } & 570 & 486.9 & 0 & 861.9 & 347.69 & 11.4 \\
\hline $\mathrm{GP}_{0}$ & 570.9 & $\mathrm{CS}$ & & \\
\hline $\mathrm{GP}_{1}$ & 570 & 292.14 & 194.7 & 775.7 & 347.69 & 11.4 \\
\hline $\mathrm{GP}_{2}$ & 570 & 146.07 & 340.8 & 775.7 & 347.69 & 11.4 \\
\hline $\mathrm{GP}_{3}$ & 570 & 146.07 & 340.8 & 775.7 & 347.69 & 11.4 \\
\hline $\mathrm{GP}_{4}$ & 570 & 146.07 & 340.8 & 775.7 & 347.69 & 11.4 \\
\hline $\mathrm{GP}_{5}$ & 570 & 146.07 & 340.8 & 775.7 & 347.69 & 11.4 \\
\hline
\end{tabular}

\subsection{Mixing and Curing}

First the mixing process started with the dry mixing of the coarse and fine aggregate for $1 \mathrm{~min}$. Further, fibres were added into the dry mixture for another $1 \mathrm{~min}$. Finally, solution was added slowly. The fresh concrete was cast in $100 \mathrm{~mm} \times 100 \mathrm{~mm} \times 100 \mathrm{~mm}$ cubical mould for compressive strength and in diameter $100 \mathrm{~mm}$ and $200 \mathrm{~mm}$ height cylinder moulds for split tensile strength separately. In this study, each test result values consist of the average of trial test. After casting, specimens were cured at heat curing at $60^{\circ} \mathrm{C}$ for $24 \mathrm{hrs}$ in hot air oven until the time of test at the intervals of 3 days, 7 days and 28 days.

\subsection{Compressive Strength:}

This test was carried out on three specimens following the procedure described by IS [516-1959]. Compressive strength measurements were carried out using tones of compression testing machine with a loading rate of approximately $140 \mathrm{~kg} / \mathrm{m}^{2} / \mathrm{min}$.

\subsection{Split Tensile Strength:}

According to IS $5816-1999$, the size of the cylinder is $100 \mathrm{~mm}$ diameter and $200 \mathrm{~mm}$ height. Applied load in specimen without shock and increased continuously within the range of $1.2 \mathrm{~N} /\left(\mathrm{mm}^{2} / \mathrm{min}\right)$ to $2.4 \mathrm{~N} /\left(\mathrm{mm}^{2} / \mathrm{min}\right)$.

\section{Results and Discussions}

\subsection{Compressive Strength}

The average compressive strength of geopolymer concrete with and without glass fibers at the age of 3 days, 7 days and 28 days with heat curing at $60^{\circ} \mathrm{C}$. The compressive strength of FRGPC (Fibre reinforced geopolymer concrete) was increased with respect to increase in percentage volume fraction of glass fiber. The addition of $0.5 \%, 1 \%, 1.5 \%$ and $2 \%$ of glass fiber to concrete does not to increase the compressive strength while the compressive strength of fibre reinforced geopolymer concrete composites specimens with $2 \%$ of glass fiber volume fraction of glass fiber shows maximum compressive strength.

Table 2: Compressive strength of FRGPC

\begin{tabular}{|c|c|c|c|}
\hline \multirow{2}{*}{$\begin{array}{c}\text { Mix } \\
\text { ddentity }\end{array}$} & \multicolumn{3}{|c|}{ Oven curing in $\mathrm{N} / \mathrm{mm}^{2}$} \\
\cline { 2 - 4 } & 3 days & 7 days & 28 days \\
\hline $\mathrm{GP}_{0}$ & 27.54 & 39.45 & 41.56 \\
\hline $\mathrm{GP}_{1}$ & 35.45 & 55.34 & 45.39 \\
\hline $\mathrm{GP}_{2}$ & 34.56 & 46.47 & 47.54 \\
\hline $\mathrm{GP}_{3}$ & 35.43 & 49.54 & 51.25 \\
\hline $\mathrm{GP}_{4}$ & 37.34 & 50.35 & 55.34 \\
\hline $\mathrm{GP}_{5}$ & 38.45 & 54.85 & 59.26 \\
\hline
\end{tabular}

From table 2 and figure 1 shows that the strength variation of compressive strength of the geopolymer concrete until testing time at the interval of 3 days, 7 days and 28 days.

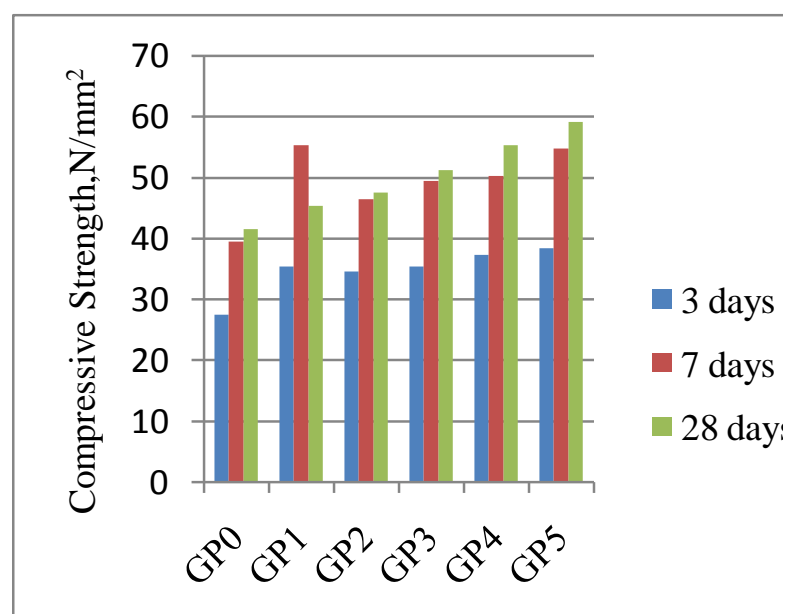

Mix Identity

Fig 1: Compressive strength variation of FRGPC

\subsection{Split Tensile Strength:}

From table 3 and figure 2 shows that the strength variation of split tensile strength of the geopolymer concrete with copper slag and glass fibre at the interval of 7 days and 28days.

Table 3: Split tensile strength of FRGPC

\begin{tabular}{|c|c|c|}
\hline \multirow{2}{*}{ Mix Identity } & \multicolumn{2}{|c|}{ Split Tensile Strength in $/ \mathrm{mm}^{2}$} \\
\cline { 2 - 3 } & 7 days & 28 days \\
\hline $\mathrm{GP}_{0}$ & 3.12 & 4.15 \\
\hline $\mathrm{GP}_{1}$ & 3.37 & 4.21 \\
\hline $\mathrm{GP}_{2}$ & 3.66 & 4.98 \\
\hline $\mathrm{GP}_{3}$ & 4.77 & 5.19 \\
\hline $\mathrm{GP}_{4}$ & 5.04 & 5.90 \\
\hline $\mathrm{GP}_{5}$ & 5.05 & 6.18 \\
\hline
\end{tabular}




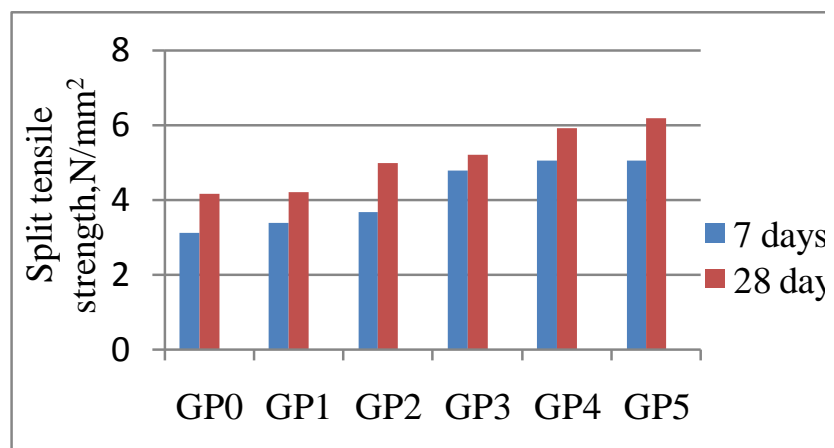

Mig 2: Split tensile strength variation of FRGPC
IAntits

\subsection{Water Absorption:}

The water absorption test has been carried out according to ASTM C646-82, to study the relative porosity or permeability characteristics of glass fibre reinforced geopolymer concrete at 28 days. The size of the cube specimen is $100 \mathrm{~mm} \times 100 \mathrm{~mm} \times$ $100 \mathrm{~mm}$.To calculate the water absorption is the difference between the satured mass and oven dried mass expressed as a fractional percentage of oven dried mass gives the water absorption. From table 4 show that the results for water absorption in geopolymer concrete with and without glass fibers.

Table 4: Results for water absorption

\begin{tabular}{|c|c|c|c|c|c|}
\hline \multirow[b]{2}{*}{ Mix } & \multirow{2}{*}{$\begin{array}{c}\text { Initial } \\
\text { Weight } \\
(\mathrm{kg})\end{array}$} & \multicolumn{2}{|c|}{ Weight kg } & \multicolumn{2}{|c|}{ Water absorption (\%) } \\
\hline & & $\begin{array}{c}\text { At } 30 \\
\text { minutes }\end{array}$ & $\begin{array}{l}\text { At } 24 \\
\text { hours }\end{array}$ & $\begin{array}{c}\text { At } 30 \\
\text { minutes }\end{array}$ & $\begin{array}{l}\text { At } 24 \\
\text { hours }\end{array}$ \\
\hline $\mathrm{GP}_{0}$ & 2.36 & 2.36 & 2.39 & 0 & 1.27 \\
\hline $\mathrm{GP}_{1}$ & 2.40 & 2.41 & 2.41 & 0.41 & 0.41 \\
\hline $\mathrm{GP}_{2}$ & 2.84 & 2.84 & 2.86 & 0 & 0.70 \\
\hline $\mathrm{GP}_{3}$ & 2.70 & 2.70 & 2.70 & 0 & 0 \\
\hline $\mathrm{GP}_{4}$ & 2.71 & 2.71 & 2.71 & 0 & 0 \\
\hline
\end{tabular}

\section{Conclusion:}

The geopolymer concrete is a best alternative to ordinary Portland cement concrete. Class F fly ash based geopolymer concrete has excellent compressive strength within short periods and suitable for structural applications.

From the test result, the compressive strength and Split tensile strength of $2 \%$ glass fiber reinforced geopolymer concrete found to be increase in strength decreased in water absorption when compared to conventional geopolymer concrete with and without copper slag. Hence $2 \%$ concentration of glass fiber is found to be optimum dosage for our research.

\section{Acknowledgement}

The authors are thankful to the management of Vel Tech High Tech Dr Rangarajan Dr Sakunthala Engineering College, Chennai, Tamilnadu, India, for providing lab facilities to carry out this research work.

\section{References}

[1] Krishnan L, S. Karthikeyan, S. Nathiya, K. Suganya, Geopolymer Concrete on Eco-friendly construction materials, International journal of research in Engineering and Technology,11(2), 10061015.

[2] Hardjito D, Wallah, Sumajouw S E and Rangan, B.V. (2005), Fly ash Based Geopolymer Concrete, Australian Journal of Structural Engineering 6,77-85.

[3] Davidovits J (1991), Geopolymers-inorganic polymeric new materials. Journal of Thermal Analysis. 37(8),1633-56.
[4] Anuradha R, Sreevidya V, Venkatasubramani V and B.V.Rangan (2011), Modified Guidelines for Geopolymer Concrete Mix Design using Indian standards, 13(3), 353-364.

[5] Weena Lokuge, Mark Reeda and Warna Karunasenab (2014), Fiber Reinforced Geopolymer Concrete with Ambient Curing for In-situ Applications. Journal of material science, 49 (12), 4297-4304.

[6] Vignesh P,Nandhini N and Krishnaraja Ramasamy (2014), Mechanical Properties of Geopolymer Concrete Using M-Sand and Glass Fibers. An International journal of innovative research in science, engineering and technology, 3(2), 2347 - 6710.

[7] Aslam hutagi,Dr R B Khadiranaikar, Reshma Shembile (2014),A Study on Fiber Reinforced Geopolymer Concrete, Journal of Civil Engineering Technology and Research Volume 2(1), 15-22.

[8] Bhalchandra S A, Bhosle A Y(2013), Properties of Glass Fiber Reinforced Geopolymer Concrete, International Journal of Modern Engineering Research, 3(4), 2007-2010.

[9] Faiz Uddin Ahmed shaikh (2013), Review of mechanical properties of short fibre reinforced Geopolymer composites, Construction and building materials 43,37-49.

[10] Arnaud Castel, Steve Foster and James Aldred (2014), TimeDependent Behavior of a Class F fly ash-Based Geopolymer Concrete, International Journal of Research in Engineering and Technology, 3(13), 2321-730.

[11] Mahendran K, Arunachelam N (2015), Study on utilization of copper slag as fine aggregate in geopolymer concrete. International Journal of Applied engineering research, 10(53),336-40 